\title{
THEOLOGY AND GENDER IN THE AFRICAN CONTEXT: AN EDITORIAL
}

\author{
Ernst M Conradie \\ Department of Religion and Theology \\ University of the Western Cape
}

$\mathrm{M}$ ost of the articles in this edition of Scriptura derive from a conference of the Theological Society of South Africa that was held at the Hammanskraal campus of the University of Pretoria from 20-22 June 2003. The topic of the conference was "Theology and gender in the African context".

There can be no doubt about the importance of this theme in the current South African and African contexts. The papers that are included in this volume of Scriptura make important but limited contributions to the ongoing debates in this regard. The limitations are at least twofold:

Firstly, a painfully obvious observation has to be made here, namely that all but one of the essays included in this volume were written by men. There is indeed a need for gender-sensitive theological reflections on the construction of masculinity. However, this is far exceeded by the need for theological publications by women for women and dealing with issues that women regard as important. Such a need has been addressed, for example, by publications emerging from the Circle of African Women Theologians. However, accredited journals such as Scriptura should also be a forum where this can take place. It may be noted here that several of the papers read and discussed at the conference of the Theological Society of South Africa could not be submitted for publication for various reasons. These included thought provoking contributions by Mercy Amba Oduyoye, Ronell Bezuidenhout and Isabel Phiri. ${ }^{1}$ It should be clear, though, that some further homework will be necessary in this regard.

Secondly, the topics of the contributions included here do not cover the full spectrum of themes that are typically associated with debates on theology and gender in the African context. There is no discussion on the work of the Circle of African Women Theologians, ${ }^{2}$ except for Holder Rich's contribution on Madagascar no reflection on violence against women (rape, ${ }^{3}$ domestic violence, etc. ${ }^{4}$ ), little on women in the ordained ministry, ${ }^{5}$ no detailed investigation of gender issues in relation to HIV/AIDS, ${ }^{6}$ no extensive critique of patriarchy in the African context, and so on and so forth. The articles that are included in this volume do cover a highly diverse range of interesting topics: An interpretation of Proverbs 31:10-31 in the context of HIV/AIDS in Zimbabwe (Chitando); A reading of 1 Timothy against its gendered grain (West); Male

1. See the contributions by Oduyoye (2004) and Phiri (2004) to a publication on African Christian theologies in transformation. This publication is based on a conference held at the University of the Western Cape a few weeks before the conference of the Theological Society of Southern Africa. There is a considerable overlap in the contributions by Oduyoye and Phiri to these two conferences. They therefore opted not to submit their contributions for publication in Scriptura.

2. See Oduyoye (2004).

3. For a recent contribution in this regard, see Clowes and Conradie (2004).

4. See the special issue of the Journal of Theology for Southern Africa on "Overcoming violence against women and children", 114, November 2002.

5. See, for example, Ndikumana (2004).

6. See Phiri, Haddad and Masenya (2004). 
and female metaphors for God in Zimbabwe (Taringa); A critical assessment of the liberative and oppressive dimensions of the concept ntumbuluko in the Tsonga worldview (Chitlango and Balcomb); Anthropological reflections on a masculine liberation theology (Koopman); A feminist reading of the Nicene creed and the Belhar confession (Naude); Women's protest movements in Madagascar (Holder Rich); The church and homosexual clergy in New Zealand (Pratt); the Zimbabwean music industry and the ordination of women (Togarasei) and, finally, the Petrine ministry (LeBruyns).

In addition to these contributions some essays of a more general nature are also included in this volume of Scriptura. Ernst Conradie sets an agenda for taking up the responsibility of doing what he calls "contemporary theology." Jeremy Punt's essay focuses on the priority of readers in New Testament interpretation and finally, Annette Evans discusses Hellenistic and Pharaonic influences on the formation of Coptic identity.

\section{REFERENCES}

Clowes, L \& Conradie, EM (eds.) 2003. Rape: Rethinking male responsibility. Stellenbosch: EFSA.

Ndikumana, VR 2004. The ordination of women in the Zimbabwe Annual Conference of the United Methodist Church (1975-1999): Challenges and opportunities. M.TS. Thesis, Africa University, Mutare.

Oduyoye, MA 2004. Transforming the landscape of theology in Africa: Women"s agency. In: Conradie, EM (ed.): African Christian theologies in transformation. Stellenbosch: EFSA (forthcoming).

Phiri, IA 2004. Virginity testing? African women seeking resources to combat HIV/AIDS. In: Conradie, EM (ed.): African Christian theologies in transformation. Stellenbosch: EFSA (forthcoming).

Phiri, IA, Haddad, B and Masenya, M (eds.) 2004. Hear Our Cry: African Women, HIV/AIDS, and Faith Communities, Pietermaritzburg: Cluster Publications. 